\title{
MEDEDEELINGEN BETREFFENDE DE ZES KARO-LANDSCHAPPEN :
}

1. Lingga en Onderhoorigheden;

2. Baroe Djahé en Onderhoorigheden;

3. Soeka en Onderhoorigheden;

4. Sarinembah en Onderhoorigheden;

5. Koeta Boeloeh en Onderhoorigheden;

6. Si Lima Koeta. (V Koeta). ${ }^{1}$

A. Grenzen; grootte en bevolking (godsdienst en ethnoGRAFISCHE BIJZONDERHEDEN) VAN DE LANDSCHAPPEN.

1. Grenzen. De Karo-landschappen worden begrensd ten Zuiden door de residentie Tapanoeli; ten Westen door de Alaslanden (Atjeh), ten Noorden door Langkat, ten Noordoosten door Deli en Serdang en ten Oosten door de Batak-rijkjes Dolok (Silau) en Poerba.

Omtrent het juiste beloop der grenzen is nog geeu algeheele overeenstemming met enkele der omringende landschappen verkregen ; evenmin zijn de grenzen der landschappen onderling reeds geheel vastgesteld.

Met een en ander zijn de ambtenaren nog bezig; zoodra alles vaststaat, zullen de grenzen onmiddellijk worden in kaart gebracht, ten einde voor.immer grens-quaesties te voorkomen.

II. Grootte. Omtrent de grootte kunnen uit gemis aan betrouwbare kaarten geen juiste cijfers worden gegeven.

III. Bevolking. De Karo-landschappen worden bewoond door een afzonderlijken Batakstam, n.l. de Karo's; alleen in Si Pitoe Koeta Tengging bestaat de bevolking voor ongeveer $\frac{1}{3}$ uit lieden

1 Ter publiceering afgestaan door het Departement van Koloniën. RED. 
van Tobasche afkomst (hun taal is meer een Tobasch dialect), terwijl in het landschap Si Lima Koeta in ongereer gelijken getale Karoen Simeloengoen Bataks en daarnaast in het Zuiden ook vrij veel Tobaneezen worden aangetroffen.

De Karo heeft een eigen taal, gansch verschillend van het Timoersch (Simeloengoensch) en het Tobasch.

Zeer sporadisch worden Chineezen en Javanen en enkele Gajoe's en Alassers aangetroffen; vooral de eerstgenoemden vermengen zich gemakkelijk met de Karo's en nemen hun taal en kleeding over.

De bevolking der zes landschappen bestaat uit circa 7.0 .000 zielen, die meest in groote dorpen (Koeta) bijeenwonen; de dorpen tellen soms tot zestig groote huizen met per huis 8 à 10 gezinnen.

Huizenbouw. De huizen zijn zonder uitzondering hecht en sterk gebouwd met veelal zeer hooge en steile, met karbouwenhoorns gekroonde idjoekdaken. Daartusschen staan tal van rijstschuren, overdekte rijststampplaatsen, enz., alles van denzelfden solieden bouw.

Wijl al het vee in den koeta losloopt of onder de huizen wordt gekraald, laat de reinheid zeer veel te wenschen over. Ook binnen de huizen is het onzindelijk.

Karakter. De Karobatak is tamelijk oprecht en eerlijk, en heeft veel gevoel van eigenwaarde; hij is steeds gereed op te komen voor hetgeen hij meent dat zijn recht is; geen volk houdt meer van procedeeren dan het zijue.

Minder goede eigenschappen ziju dobbelzucht en lafheid, terwijl zijn werklust - in tegenstelling met die der Karovrouw - te wenschen overlaat.

Hoewel nog zeer onwetend, is hij vrij intelligent angelegd en voor ontwikkeling wel vatbaar.

Ondanks de vele onderlinge veeten, zijn toch wellicht van alle Bataksche stammen de Karo's de eenigen, wien een zekere nationale trots en vasthoudendheid eigen zijn, zoomede solidariteitsgevoel tegenover vreemdelingen en vijanden.

Godsdienst. Aan deze laatste eigenschappen is het ook voornamelijk te danken, dat zij tot nu toe vrij zijn gebleven van Maleische en audere Mohammedaansche invloeden.

De geheele bevolking is nog heidensch. In de eerste plaats vereeren zij de geesten (begoe) der voorouders; eerst in de tweede 
plaats de godheid, den Debata, hoogstwaarschijnlijk het Hindoesche element van hun godsdienst, bestaande uit een soort drieëenheid van een bovenaardschen, aardschen en onderaardschen god.

Als heidenen levert het Karovolk een geschikt object op voor de Christelijke zending; een drietal zendelingen zijn thans op de Hoogvlakte werkzaam, een van wie aan het hoofd staat van de leprozenkolonie te Laoe Simomo (nabij Kaban Djahé), waar thans reeds circa 130 lijders worden verpleegd.

Bij tactvol optreden van de zendelingen - en hiervan kan slechts met lof worden gewaagd - kan de zending een goede toekomst tegemoet gaan, mits het binnendringen van Maleiers en Mandailingers, op wier komst de bevolking absoluut niet is gesteld, ook worde tegengegaan.

Een eigenlijke priesterstand bestaat in de Karo-landen niet; bij de oproeping der geesten wordt weliswaar van een goeroe (een medium, tevens wichelaar en medicijumeester) gebruik gemaakt, maar op de openbare aangelegenheden oefenen die goeroe's bijna geen invloed uit.

Huwelijk. De adat in de Karo-landen is in hoofdzaak gegrond op het patriarchant.

De bevolking is verdeeld in vijf stammen (marga), t. w. KaroKaro, Taringen, Giuring, Perangin-angin en Sembiring, die elk weer in tallooze ondermarga's zijn verdeeld.

Iu de 4. eerstgenoemde marga's heerscht exogamie (man en vrouw moeten tot verschillende stammen behooren), in de marga Sembiring niet, waarom men meent, dat deze van vreemde, overzeesche, waarschijnlijk Hindoesche afkomst is. Immers in de overige marga's is het huwelijk met iemand vau denzelfden stam zóó streng verboden, dat het een der zeer weinige adat-overtredingen is, waarop de doodstraf staat (al bleef deze ook af koopbaar).

$\mathrm{Al}$ is ook het geslachtelijk verkeer tusschen jougelieden zoo goed als geheel vrij - op ongereptheid van de vrouw vóór het huwelijk wordt geen prijs gesteld -, streng wordt gewaakt tegen intiemen omgang tusschen personen, die niet met elkaar mogen huwen, waarvan, uaar het volksgeloof, allerlei rampen als misgewas, ziekten enz., het gevolg kunnen zijn.

De stam, waartoe de moeder behoort, noemt men "berei-berei" ; terwijl nu het huwelijk van een vrouw met een man, wiens marga dezelfde is als de berei-berei der vrouw, verboden is, is het huwelijk 
tusschen een man en een vrouw, wier marga dezelfde is als de berei-berei van den man, geoorloofd. Zeer gewenscht wordt zelfs geacht een verbintenis van een man met zijn "impal", d. i. de dochter van zijn moeders broeder.

De meest voorkomende huweijksvorm is het "noengkoen".

Heeft een jongeling zijn keuze gevestigd, dan laat hij anzoek doen bij de ouders van het meisje; zoodra men het over den bruidschat eens is geworden - deze bedraagt f 50 à f $120-$, wordt door zijne vrouwelijke bloedverwanten een deel daarvan, pl. m. f 10, de zoogenaamde "penadengen", aan de ouders aangeboden, waarna het meisje naar de woning harer annstaande ouders wordt overgebracht; hier blijft zij eenige dagen, soms ook wel tot het huwelijk.

De jongelieden worden thans als verloofden beschouwd.

Zoodra nu de goeroe den gunstigen dag voor de huwelijksvoltrekking heeft vastgesteld, komen beide partijen met huune penghoeloes en bloedverwanten bijeen; de bruidsschat en de zoogenaamde "simetjoer" (kleiue geschenken in geld aan de penghoeloes en enkele familieleden van de bruid) worden betaald, waarna de plechtigheid (erdemoebajoe), welke met een feestmaal eindigt, plaats heeft en daarmede de huwelijksvoltrekking is afgeloopen.

Meestal op deuzelfden dag volgt het "moekoel", waarbij de jonggehuwden samen uit één bord eten, ten teeken dat zij zich thans als echtgenooten kunnen beschouwen.

Het huwelijk is een koop; de vrouw wordt daardoor het eigendom van den man en diens familie.

Kinderverloving komt veelvuldig voor; het huwelijk wordt eerst voltrokken als de huwbare leeftijd is bereikt.

Echtscheiding komt mede tamelijk veel voor; als regel is kinderloosheid de aanleiding, of echtbreuk, het zwaarste vergrijp dat een vrouw kan begaan. Mishandeling, kwaadwillige verlating, kan voor de vrouw een reden zijn om ontbinding van het huwelijk te vorderen ; de eisch wordt behandeld door den balei der penghoeloes, die, als verzoening niet mogelijk blijkt, den eisch kan toestaan. De naaste maunelijke bloedverwant van den man erft bij diens overlijden de weduwe.

Erfrecht. Alleen de zoons erven, en van dezen ontvangen de oudste en de jongste een grooter aandeel dan de anderen. Waardigheden gaan over op den oudsten zoon; bij ongeschiktheid van dezen heeft de jongste den voorrang boven de andere broeders. 
Met uitzondering van de dochters van vorsten, erven vrouwen niet; zij hebben slechts recht op de helft der sieraden en kleederen van haar overleden moeder.

Adoptie is onbekend.

Overlijden. Bij overlijden wordt het lijk in een mat gewikkeld en verbrand; soms wordt het vooraf begraven of aan een stelling aan den kant van een ravijn opgehangen.

Bij aanzienlijke hoofden en goeroes wordt het lijk in een uitgeholden boomstam gelegd en deze goed afgesloten; het lijkenvocht wordt door eene opening aan de ouderzijde en verder door een bamboebuis naar den grond afgevoerd. Na eenigen tijd worden de overblijfselen verbrand, met uitzondering van den schedel, welke bewaard wordt in een schedelhuisje, in de nabijheid der woning.

$\mathrm{Bij}$ den Sembiring-stam bestaat nog een eigenaardig algemeen doodenfeest, dat eens in het jaar, ook wel om de 2 à 4 jaren wordt gevierd eu waarbij de door het vuur onverteerde beenderen in potten of kleine vaartuigen worden gelegd, die men dan de rivier laat afdrijven.

Besnijdenis. Besnijdenis heeft alleen bij knapen plaats en wel door incisie; de operatie verrichten zij aan zichzelven, als regel in het $15^{\text {de }}$ levensjaar of daaromtrent.

Tandenvijlen. Het tandenvijleu is een algemeen voorkomend gebruik; het wordt toegepast zoowel bij jongeus als bij meisjes, doorgaans op 9 -jarigen leeftijd.

Slavernij en pandelingschap. Slavernij kwam reeds vóór ons optreden bijna niet voor; slechts enkele Karo's hielden een Toba-slavin. De adat van den Karo kent ook feitelijk slechts het pandelingschap, dat al mede in de praktijk weinig bezwarend is; immers plegen nimmer overmatige boeten te worden opgelegd of schulden te worden aangegaan, zoodat de meesten in staat ziju, al dan niet met behulp van familie, de schulden of de boeten te voldoen.

Overigens is reeds dadelijk door ons bepaald, dat alle slavernij en pandelingschap op 1 Januari 1910 moeten hebben opgehouden te bestaan, een maatregel, welke in verband met het bovenstaande, in de Karo-laudschappen geeue bezwaren uitlokte. 
B. Bergen en rivieren (Met opgave van de bevaArbaArHEID); WATERLEIDINGEN ; WEgEN EN BRUGGEN.

Bergen en rivieren. Zie hieromtrent onder rubriek D.

W a terleidingen. Waterleidingen van eenige beteekenis worden op de Hoogvlakte niet aangetroffen.

W egen en bruggen. De omstandigheid, dat de Karo-hoogvlakte doorsneden is van diepe, steile ravijnen, makt den aanleg van wegen vrij bezwaarlijk; daar belangrijke omleggingen, ten einde die ravijnen te ontloopen, daardoor onvermijdelijk zijn.

In alle richtingen wordt het land doorkruist door voetpaden, waarvan eenigen ook voor ruiters begaanbaar ziju.

Sedert onze vestiging zijn de aanleg en de verbetering der wegen krachtig ter hand genomen. De volgende voor voertuigen alleszins geschikte wegen worden thans aangetroffen :

a. de weg van Tengkeh (op den rand der Hoogvlakte gelegen, nlwaar de groote transportweg van Deli eindigt) via Kaban Djahé naar Sariboe Dolok; deze weg is lang 51 K.M.

b. de weg van Kaban Djahé via Kandebata, Sarinembah, Koeala tot nabij Koeta Bangoen, lengte pl. m. 48 K.M. Van dezen weg, welke de aangewezen transportweg is naar de Alaslanden en thans reeds als zoodanig wordt benut, zal het gedeelte Kwala-Laoe Baleng dit jaar van Gouvernementswege worden aangelegd.

Voorts is in aanleg een weg van Sariboe Dolok naar Poerba en naar het Toba-meer, terwijl mede een tracé is gevonden ter verbinding van de afdeelingshoofdplaats met Bangoen Poerba, het eindstation der Deli-spoor, vanwaar door de Boeajapas de weg reeds is aangelegd tot Kota Bajoe an den rand der Hoofdvlakte.

Waar noodig, zijn in die wegen bruggen aangebracht, w.o. geen bijzondere kunstwerken voorkomen.

\section{Samenstelling van de landschappen met opgave VAN KAMPONGS.}

De administratieve indeeling der Karo-landen in zes landschappen is een creatie van ons (Staatsblad 1906, No. 531 en 1908, $\mathrm{N}^{\circ}$. 86). Hoe wij daartoe gekomen zijn, zal worden toegelicht onder 
Radja Pajoeng, Djoema Radja, Berkala, Keling, Djermoeda, Soeka Serbakti, Torong, Pertegoehĕn, Lingga Djoeloe, Katjariboe, Nangbelawan, Koeta Tengah, Gamběr, Koeta Tonggal, Běkĕrah, Si Matjem, Soekanaloe, Si Garang garang, Toradja Goegoeng, Toradja Bĕrněh, Kebajakĕn, Koeta Mbĕlin, Koeta Negeri, Oedjoeng Pinto, Naman, Deskati, Oedjoeng Tĕran, Dairam, Soeka Tepoe, Soeka Nděbi, Kaban Djahé, Kĕtarèn, Berhala, Sĕmoera, Ketepoel, Kaban, Soemboel, Goeroe Singa, Raja, Berrastagih, Petjerien, Laoe Goemba, Batoe Karavg, Tandjoeng, Nari Goenoeng, Djandi Meriah, Penampien, Selandi, Pajoeng, Tandjoeng Merawa, Koeta Galoeh, Perbadji, Tandjoeng Poleau, Rimau Kajoe, Goenoeng Merlawan, Roemindang, Rijoeng, Soesoek, Liang Datei, Pernautian, Laoe Lingga, Kandebata, Beganding, Oedjoeng Pajoeng, Barastepoe, Goeroe Kinajan, Soeka Radja, Merdingding, Koeta Mbaroe, Temboeraïen, Tandjong Poelau, Bintangmariah.

b. In het landschap Soeka en Onderhoorigheden :

Soeka, Koeta Keipar, Sēbērdja, Sampoen, Boekit, Soegihēn, Adji Boehara, Adji Djoeloe, Adji Djahei, Adji Mbelang, Bertah, Koeta Djoeloe, Koeboe Tjolija, Oedjoeng Sampoen, Djawa, Mĕlas, Radja 'Tengah, Koeta Balei, Koeta Radja, Koeta Radja Goenoeng, Koeta Gerat, Bloeloeh Pantjoer, Koeta Boeah, Laoe Kidoepĕn, Naga, Namoe Soerau, Boenoeraja,-Singga, Tongging, Meriah Tongging, Sihodon hodon, Sibolangit, Pangambota, Negeri Tongging, Garingging, Nagara, Partibi, Adjinĕmbah, Manik Moelia, Laoe Riman, Katjinaboen, Taloen Koeta, Koeboe, Adji Kinajan, Radja Kinajan, Ergadji, Dokan.

c. In het landschap Baroe Djahé en Onderhoorigheden :

Baroes Djahé, Boentoe, Baroes Djoeloe, Basem, Boelan Djoeloe, Tandjoeng Baroes, Taloen Baroe, Tangkidik, Tandjoeng Mereihan, Pariboeën, Penampein, Pekenteboe, Djoema Padang, Oedjoeng Baudar, Oedjoeng Balei, Kaboeng, Roemah Rih, Serdang, Si Bĕrtēng, Goerisĕu, Soeka Djoeloe, Soeka Naloe, Boelan Djahé, Si Naman, Radja Sinembah, Rimau Manis.

d. Iu het landschap Koeta Boeloeh en Onderhoorigheden:

Koeta Boeloeh, Djinaboen, Laoe Boeloeh, Soeka Tĕndĕl, Koeta Boeloeh Goegoeng, Boeah Radja, Amboeridi, Belingking, Djoema Ramboeng, Laoe Gambang, Laoe Kĕrsěk, Mertĕloe, Sampei Raja, $\mathrm{Si}$ Besi Besi, Serpang, Merdingding, Perboelan, Oeroek Doea Ngawan, Laoe Pertemboengĕn, Raja Bĕntar, Riman Boenga, Rambah Panoengsang, Laoe Simomo, Laoe Perira, Loning, Laoe Gerat; 
Gara Bina, Teroemboe, Tandjoeng, Koeta Belin, Koeta Gadjang, Koeta Mbaroe, Kinang Koeng, Koeta Mbaroe Poenti, Koeta Pengkih, Karang Batoe, Koeta Mbaroe, Koeta Toealah, Boekit, Bauban, Batoe Pah Pah, Boeloeh Pantjoer, Boeloeh.Mbilang, Oeroek Gelima, Paja Goegoeng, Goenoeng Meriah, Batoe Mamak, Oedjoeng Deleng, Bisangkal, Tandjoeng Merahe, Rih Tengah, Negeri Djahe, Bandar Lingga, Soloe.

$e$. In het landschap Sarinembah en Onderhoorigheden :

Sarinembah, Singamanik, Moentei, Goeroe Benoea, Kinepen, Boeloeh Naman, Koeta Mbaroe, Tandjong Beringin, Negeri, Tjawer Moentei, Koeta Gerat, Baroeng Kersap, Kabau Tosah, Bijak Nampei, Goenoeng Manoempak, Tandjoeng Balei, Gerat Boesoek, Koeta Soeah, Djoehar, Kidoepen, Kerijahan, Betoeng, Koeta Belin, Koeta Radja, Radja Berneh, Koeta Goegoeng, Batoe Mamak, Soeka Baban, Soegihen, Negerie, Bekilaug, Sigenderang, Kem Kem, Koeta Galoeh, Perbesi, Kerapat, Limong, Keranda, Koeta Gerat, Koeala, Goenoeng, Radja Tengah, Koeta Boeharo, Koeta Bangoen, Paja Gara, Laoe Baleng, Laoe Peradap, Laoe Melas, Laoe Peranggoenen, Tandjoeng Balei, Koeta Toealah, Doerian Roegoen, Soeka Djoeloe, Pergendangan, Koeta Djahim, Djandi.

$f$. In het landschap Si Lima Koeta :

Nagasariboe, Mardingding, Bandar Sariboe, Nagabosar, Nagatimboel, Naga Mariah, Rakoet Besi, Sariboe Djandi, Djandi Sariboe, Dolok Sariboe, Dolok Pariboean, Doesoen, Bandar Howoel, Djandi Howoel, Bangoen Dolok, Bandar Raja I, Bandar Raja II, Sariboe Dolok, Si Toeri Toeri, Bangoen Sariboe, Djandi Mariah, Sipan, Bagei I, Bagei II, Dolok Mariah, Tampei Tampei, Hopoan, Koeta Moeda, Sopeng, Koeta Mbaroe, Pariboean, Perdjalangan, Langit Sinombah, Si Meiloek, Si Markalawas, Koeta Djoheian, Poerba Sinomba, Bagot Lingga, Si Palom, Parmonangan.

\section{Grondgesteldheid.}

Het gebied der Karo-landschappen bestaat uit de Hoogvlakte ten Noorden en ten Noordwesten van het Toba-meer; uit de die Hoogvlakte omringende bijna geheel onbewoonde gebergten en, in 't uiterste Westen, uit het woeste, zeer moeilijk begaanbare bergland Liang Melas, dat naar het Zuiden veel lager wordt, en, hier, ten Westen van het Salitgebergte, dat de eigenlijke Hoogvlakte afsluit, zelfs een smal laagland vormt, slechts pl. m. 150 Meter boven zee. 
Bijna de geheele Hoogvlakte is met alang-alang of met andere harde gras- en rietsoorten en met varens bedekt. Het geheel biedt over het algemeen een dor aspect aan.

De vruchtbaarheid van den bodem is het geringst in het Oosten en neemt meer en meer toe naarmate men Westelijker en dus lager komt. Het niveau der Hoogvlakte daalt van 1400 Meter boven zee (Si Lima Koeta) geleidelijk tot 700 Meter (bij Perbesi in het Westen).

Moge in vroegere eeuwen de Hoogvlakte bewoud zijn geweest, hetgeen nog niet zeker is, door voortdurend ladang-aanleg is het bosch geheel verdwenen, en als gevolg ook van den toch reeds zoo poreusen bodem het water zeer schaarsch.

Slechts in de onmiddellijke omgeving der kampongs en op enkele als heilig bekend staande plaatsen, treft men nog eenig bosch aan.

Tal van meest zeer diepe ravijnen doorsnijden het plateau, beddingen van vroegere rivieren, die langzamerhand tot oubeteekenende beekjes zijn geworden.

Slechts één rivier van beteekenis treft men nog aau, n.l. de Laoe Biang, ontspringende op de hellingen van de vulkanische kegels Singgalang en Si Pisau-Pisau (of Tandoek Banoewa) in het landschap Si Lima Koeta; zij doorsnijdt de geheele hoogvlakte en stroomt verder naar Langkat, waar de benedenloop als Soengei Wampoe bekend is (eerst daar bevaarbaar).

Is, gelijk gezegd, de toestand van den bodem in het Westen gunstiger dan in het Oosten, en groeit daar ook de kokospalm, daartegenover heeft men daar meer misoogsten tengevolge van de hevige droogten.

Op de Hoogvlakte zelve treft men, behalve de beide evengenoemde vulkanische kegels nog den vulkaan Sinaboeng aan, den hoogste in die streken (2417 Meter). Van het grensgebergte ten Noordeu en het Noordwesten is de vulkaan Sibajak (2172 Meter) de hoogste top.

Wat delfstoffen aangaat, is slechts bekend, dat in het gebergte in het Noorden van het landschap Koeta Boeloeh goud wordt aangetroffen; vroeger werd het ook door de bevolking gewounen.

Het klimaat op het plateau is zeer koel, vaak zelfs ruw. Dikwerf waaien zware stormen over de vlakte; hevige stortregens komen zelden voor, bewolkte en mistige dagen daarentegen veelvuldig. 
E. NiJverheid, landbouw, veEteelt, Jacht en visscheriJ, HANDEL EN SCHEEPVAART.

Omtrent deze onderwerpen valt weinig belangrijks aan te teekenen. Van kunstzin is de Karo niet ontbloot; deze uit zich in de goudsmeedkuust, in hout- en bamboe-snijwerk, en in het weven.

Het hoofdmiddel van bestaan der geheele bevolking is de rijstcultuur, die voornamelijk op droge velden wordt gedreven. Sawah's treft men, met enkele uitzonderingen, slechts aan in de ravijnen, zoomede op enkele, niet te steile berghellingen naar het Toba-meer. Irrigatie van sommige gedeelten der Hoogvlakte is wellicht niet onmogelijk, doch de poreusheid van den bodem zal steeds een bezwarenden factor blijken te zijn:

Is het weer niet ongunstig, dan levert de Hoogvlakte reeds thans voldoende rijst voor de eigen behoefte op; in gunstige jaren heeft uitvoer plaats.

De Karo voelt veel voor den rijstbouw ; aan bewerking en onderhoud zijner velden wordt behoorlijk zorg besteed; bemesting, ploegen en eggen zijn hem geenszins vreemd.

Behalve rijst, worden nog verbouwd djagoeng, groenteu, w. o. ook aardappelen, terwijl verder van belang is de cultuur van den arenpalm, in het bijzonder voor het winnen van idjoek, de algemeene dakbedekking der Karosche huizen.

Een voornaam bestaansmiddel voor den Karo is de teelt van paarden en vee, w. o. ook varkens. Qualiteit zoowel als quantiteit van den veestapel zijn echter zeer achteruitgegaan door de gedurende tal van jaren vóór onze vestiging geheerscht hebbende veeziekten, welke thans door de veterinaire maatregelen onzerzijds een einde schijnen te hebbeu genomen. Bovendien besteedt de Karo weinig zorg aan zijn veestapel. Runderen zoowel als karbouwen worden slechts zelden gekraald, doch plegen den nacht onder de huizen door te brengen; ook de varkens loopen in vrijheid rond en schieten zich onder de huizen op. Vau de paarden worden de hengsten steeds, de merries met hare veulens meestal, behoorlijk gestald, doorgaans ook onder de huizen. Door het bestuur zijn maatregelen getroffen om le veeteelt uit haar verval op te heffen.

Jacht eu visscherij ziju van weinig beteekenis, terwijl mede omtrent den handel niets bijzonders valt aan te teekenen. 


\section{F. Bestudr over de LANDSchappen: HuN SAMENS'TELLING EN GE-} SCHIEDENIS, W. O. TE BESPREKEN DE INKOMSTEN DER HOOFDEN EN DE LANDSCHAPSKASSEN.

Bij ons optreden bestond het Karo-volk feitelijk uit een zeer groot aantal republiekjes (oeroeng). De oeroeng is dan ook de oorspronkelijke bestuurseenheid van het Karo-land. Soms bestond de oeroeng slechts uit één dorp (de zoogenaamde zelfstandige Koeta`s), soms uit meerdere, en alzoo een landschap vormende.

De dorpen, voorzoover zij van eenig belang zijn, bestaan weer uit een aantal wijken of huizen-complexen (kesein), aan het hoofd waarvan een wijkhoofd (penghoeloe kesein) staat.

De gezamenlijke wijkhoofden nu vormen het dorpsbestuur, en de gezameulijke dorpsbesturen het landschapsbestuur.

Uit den aard der zaak speelden niet alle wijkhoofden een even belangrijke rol; hoewel in beginsel allen gelijk waren, traden toch gaandeweg enkelen meer op den voorgrond en wel de wijkhoofden van het moederdorp, dat doòrgaans ook het meest bevolkte was.

Die personen, perbapaäns genaand, waren dus vooral naar buiten de vertegenwoordigers van het landschap (oeroeng), de hoofden dus; soms waren er twee, vaak echter ook 3 of 4 in een laudschap.

Nadat nu, na de annexatie, door de Regeering tot den indirecten bestuursvorm was besloten, werd nagegaan welke hoofden de korte verklaring hadilen af te leggen; het ging toch niet aan al de talrijke landschapjes daartoe toe te laten. Onderzocht werd of niet meerdere oeroengs tot oeroeng-complexen konden worden saamgevoegd, mede ter bevordering van een goed bestuur over al die streken, wijl het toelaten van al te kleine bestuurseenheden belemmerend werkt.

Als uitgangspunt om tot het doel te geraken, diende nu de wellicht van 1 à 2 eeuwen her dateerende Atjehsche instelling der "Radja berampat".

In vroegere tijden toch heeft Atjeh op de Hoogvlakte een weliswaar weinig daadwerkelijke, maar toch niet geheel denkbeeldige suprematie uitgeoefend.

Weinig daadwerkelijk, wijl immers de Islam absoluut niet in het Karo-land is doorgedrongen; toch niet geheel onbeteekenend, wijl volgeus de overlevering van Atjehsche zijde is getracht invloed op de zaken in de Karo-landschappen uit te oefenen door aan de vier, dat rijk het best gezinde en machtigste Karo-radja's, t. w. de oeroenghoofden (Sibajak) van Lingga, Sarinembah, Baroe Djahé en 
Soeka een zekere suprematie toe te kennen boven hunne collega's ten einde zoodoende het gezag in die streken meer te centraliseeren.

Sedert dien hebben deze hoofden steeds bekend gestaan als de "Radja berampat" der Karo's en werden zij eenigszins de "primi interpares" onder de landschapshoofden.

Toch heeft dit instituut zich niet verder ontwikkeld; integendeel, werkelijke macht over de overigen hebben zij nimmer bezeten, en zelfs uiterlijk worden zij al zeer weinig, vaak in 't geheel niet, als van hoogeren rang beschouwd.

Die instelling wees nochthans ons den weg aan, dien wij moesten inslaan. Hoe weinig dan ook, zij stonden althans iets hooger dan de anderen, waren voorts als oeroenghoofden nog al van beteekenis, terwijl bij de verwikkelingen, die tot de annexatie leidden, bovendien drie hunner onze politiek hadden gesteund.

Om die redenen werd de Atjehsche creatie de basis der nieuwe bestuursorganisatie, met die uitbreiding in het belang eener goede indeeling, dat de sedert lang met ons bevriende Sibajak van Koeta Boeloeh als vijfde aan het 4-tal hoofdradja's werd toegevoegd.

Een zesde éénheid werd het half Simeloengoensche landschap Si Lima Koeta, waar de hoofdradja, de Toehan Nagasariboe, als van Simeloengoensche afkomst den titel voert van "Toehan".

De overige oeroengs (ook dus de zelfs'andige dorpen) werden als onderhoorigheden ondergebracht bij die zes eenheden, welke voortaan "landschappen werden genoemd, aan welker hoofd landschapshoofden of Sibajaks (in Si Lima Koeta: Toehan) staan.

De landschappen zijn onderverdeeld in districten onder districtshoofden of perbapaäns, onder wie weder de wijkhoofden zijn gesteld.

Slechts de landschapshoofden - in elk landschap twee, behalve in Soeka, waar slechts één Sibajak het gezag voert - onderteekenden de korte verklaring, terwijl de overige oeroenghoofden van hunne instemming daarmede bij proces-verbaal deden blijken.

Over het algemeen zijn bij deze centralisatie van het gezag geene moeielijkheden ondervonden; toch is daarmede geenszins gezegd dat de landschapshoofden nu ook allerwege reeds voldoende worden erkend en gehoorzaamd. Eerst gaandeweg zal de nieuwe orde van zaken zich kunnen vestigen, zoo ook het bestuur, zonder met overhassting te werk te gaan, in die richting blijft aansturen.

Het streven is mede daarop gericht om, waar thans nog twee Sibajaks het bestuur deelen, bij voorkomende vacatures tot een éénhoofdig gezag te geraken, waarbij wij ons de vrijheid dienen 
voor te behouden om uit beider familiën den radja te kiezen.

Rechtspraak. Gelijk bij bijna alle volken met een primitieve beschaving, dekken ook bij de Karo-Bataks bestuur en rechtspraak elkander.

In elk huis van gemiddeld acht gezinnen bekleedt een der bewoners het ambt van "penghoeloe roemah"; bij kleine geschillen tusschen de bewoners onderling is hij de aangewezen scheidsrechter, terwijl het ook wel voorkomt, dat bij zaken welke in der minne worden afgedaan, door hem kleine boeten worden opgelegd.

Blijkt ziju gezag onvoldoende dan wel geldt het een belangrijke zaak of een zaak tusschen bewoners van verschillende huizen eener zelfde wijk, dan komt in de eerste plaats het wijkbestuur, d. i. de penghoeloe kesein met zijn anak beroe en senina en doorgaans ook bijgestaan door zijn naaste familieleden voor de berechting in aanmerking.

Slaagt deze hierin niet of wel zijn lieden van een andere wijk in de zaak betrokken, dan wordt deze voor de gezamenlijke dorpshoofden gebracht, terwijl voor het geval ook deze om de een of andere redeu onmachtig blijken, dan wel bewoners van meerdere dorpen bij de quaestie betrokken zijn, de gezamenlijke radja's der oeroeng, onder voorzitterschap van den perbapaän, het geval berechten.

Tusschen dorps- en oeroengbestuur schuift zich echter in vele landschappen nog een derde rechter in; zoo waren er in de oeroeng Teloe Koeroe drie perbapaäns, de radja's van Lingga, van Serbakti en van Gadjah, en ieder hunner vormde met zijn ondergeschikte hoofden een eigen rechtbank op een eigen rechtplats (balei); slechts wanneer zoo'n rechtbank te kort schoot, werd een zaak voor de verzamelde perbapaäns gebracht.

Bij de rechtspraak wordt tusschen crimineele en civiele zaken geen onderscheid gemaakt.

Aan elkaar grenzeude landschappen bezaten steeds ergens op of nabij de grens een gemeenschappelijke balei ter berechting door de hoofden van beide oeroengs gezamenlijk, van geschillen tusschen elkanders onderdanen. Stonden de hoofden van de beide landschappen in een geschil te scherp tegenover elkaar, dan werd bij de berechting der zaak dikwijls de hulp ingeroepen van eenig machtig onzijdig hoofd, veelal, doch geenszius als regel, van een der Radja berampat. 
Rechtsquaesties ontaardden vóór de vestiging van ons gezag uit den aard der zaak dikwijls in politieke geschillen; het eene hoofd trok voor den klager het andere hoofd voor den gedaagde partij, hetzij om familierelatiën, hetzij door klinkende argumenten. Het eind was dan vaak dat het maar moest worden uitgevochten.

Bleef men nu daarbij binnen zekere perken, dan werd in zoo'n geval aan 't gevecht het karakter gegeven van een godsoordeel, dat meestal snel en niet al te bloedig verliep; doch menigmaal vergenoegde men zich daarbij niet en gaven betrekkelijk onbelangrijke rechtsquaesties aanleiding tot verbitterde oorlogen.

Sedert onze vestiging is aan die misstanden onmiddellijk een eind gekomen, en de rechtspraak in dier voege voorloopig geregeld, dat met instandhouding der wijk-, dorps- en oeroenggerechten nog landschapsgerechten zijn in het leven geroepen en daarboven nog een rechtbank van de gezamenlijke radja's berampat, welke te Laoe Tjimba zitting houdt.

Met een definitieve regeling en organisaite van het rechtswezen is het bestuur nog doende.

Hierboven werd gesproken van de anak beroe en senina.

Dit is een stelling, die in het matschappelijk zoowel als in het privaatrechtelijk leven van den Karo-Batak een zeer belangrijke rol speelt.

Iedere Karo wordt geacht een anak beroe en een senina (Karosch) of gamĕt (Timoersch) te hebben, die voor zijn handelingen moet instaan, voor zoover die voor andere personen gevolg kunnen hebben, en dus als zijne borgen kunnen worden aangesproken.

De anak beroe is steeds van een anderen stam als zijn "kalimboeboe"; b.v. A trouwt met een dochter van B; dan is B de kalimboeboe en $\mathrm{A}$ de anak beroe. Volgens de adat nu moeten de nakomelingen van A ook weer trouwen met dochters nit het geslacht B zoodat de eerste steeds anak beroe zijn van het geslacht B. Wordt van dat voorschrift afgeweken, dan moet een zoenoffer (boete) worden betaald aan de familie B om de adatband te verbreken.

De senina behoort tot denzelfden stam; doch staat zoover af in verwantschap dat een senina pas als alle anderen overleden zijn erfgenaam zou kunnen worden.

De getuigen- en zuiveringseeden worden steeds afgelegd te zamen met de anak beroe en de senina; bij den zwaarsten eed d.i. den eed op een doodskop bij zeer groote misdrijven of zaken, brengt ieder nog een tweede stel anak beroe en senina mede.

7e Volgr. IX. 
De anak beroe en sinina moeten bij huwelijk of nederzetting in een kampong dadelijk aangewezen en mogen niet meer door anderen vervangen wordeu.

Inkomsten der hoofden. Vóbr onze vestiging in de Karolanden genoten de hoofden in de eerste plaats hunne inkomsten uit den verkoop van opium, hetwelk hun monopolie was; voorts uit de rechtspraak, waarbij, behalve bij enkele zeer zware misdrijven, slechts boeten werden opgelegd, die hun toevloeiden; verder uit marktheffingen en eindelijk uit de dobbelspelen, waarvan zij een belasting hieven in den vorm van een aandeel der inzetten. Voorts genoten zij nog enkele andere adatinkornsten van minder belang.

Hunne opiumrechten zijn thans door ons afgekocht tegen een schadeloosstelling van f 10.000 's jaars begrepen in het bedrag van f 45.000 bedoeld in Bijblad $N^{\circ} 6176$; daarvoor is door het Gouvernement het licentiestelsel ingevoerd (Staatsblad $1908 \mathrm{~N}^{\text {os }} 277$ en 278) met de bedoeling om geleidelijk het gebruik van opium, dat bij den Karo nog niet diep is doorgedrongen, in ieder geval nog niet tot misbruik heeft geleid, te verminderen en zoo mogelijk eenmaal geheel te doen ophouden.

Aan de marktheffingen is een einde gekomen zonder dat het noodig voorkwam de hoofden daarvoor schadeloos te stellen; een gedeelte der boeten wordt in afwachting van een definitive regeling thans reeds in de landschapskas gestort.

Omtrent de dobbelspelen is nog geen beslissing geuomen, of namelijk al dan niet een speellicentiestelsel noodig zal blijken; voorloopig trekken de hoofden dus daaruit nog inkomsten.

Met ingang vau 1 Juli 1908 is een regeling op de bezoldigingen der Karohoofden getroffen; het bedrag van f 10.000 bovengenoemd blijft in de landschapskas; daartegenover ontvangen de hoogere hoofden uit die kas (maandelijksche) bezoldigingen tot een bedrag van f 13.500 's jaars, en de lagere hoofden, met name de wijkhoofden, éénmaal 's jaars belooningen tot een gezamenlijk bedrag van f 18.500 's jaars (daaronder niet begrepen de hoofden van Poerba en Dolok die met de Karolandschappen één gemeenschappelijke landschapskas hebben).

Landschapskassen. Met ingang van 1 Januari 1908 is ook voor de onderafdeeling Karolanden een landschapskas opgericht; welke volgens bepaalde voorschriften en naar goedgekeurde be- 
grootingen, door de betrokken Inlandsche Zelfbesturen vooraf vastgesteld, wordt beheerd.

De voornaamste inkomsten der kas zijn de Gouvernementsschadeloosstelling hiervoren genoemd, zoomede de opbrengst der met ingang van 1 Juli 1908 door de Zelfbesturen voor hunne onderdanen ingevoerde belasting op de bedrijfs- en andere inkomsten, geraamd op f 55.000 's jaars.

De begrooting der landschapskas voor het jaar 1909 bedraagt circa f 75.000 aan inkomsten en een gelijk bedrag aan uitgaven.

\section{G. Vermelding van de op de Landschappen Be'trekking}

HEBBENDE CONTRACTEN EN VERKLARINGEN.

De zgn. korte verklaringen zijn de eerste contracten ua annexatie van hun gebied, door de Karohoofden afgelegd.

Het is hier dus de plaats het een en ander aan te teekenen omtrent onze eerste anrakingen met die landschappen en de aanleiding tot die annexatie.

Vóórdat wij ons meer met de aangelegenheden dier streken gingen inlaten, heerschten aldaar toestanden in menig opzicht aan anarchie grenzende.

In het bijzonder was dit toe te schrijven aan het overgroot antal hoogere en mindere hoofden, die elkaar voortdurend de macht betwistten en wier gezag dientengevolge zeer gering en onzeker was.

Ook de oeconomische toestanden lieten alles te wenschen over; behalve dat de bevolking zeer te lijden had van de voortdurende oorlogen en veeten, van de onveiligheid en de rechtsonzekerheid, had zij bovendien nog herhaalde invallen te verduren uit de Gajoeen Alaslanden.

Van haar kant deed zij ook meermalen invallen in ons gebied, n.l. in Boven Deli en Boven Serdang; veel overlast werd daarvan echter niet ondervonden. Want, hoezeer overeenkomstig de toenmaals heerschende politiek, van krachtig optreden geen sprake was, bracht toch het eigenbelaug der Karo's mede van onze zwakke houding geen misbruik te maken, wijl zij slechts van uit de beneden landen in velerlei behoeften kouden voorzien.

Jaren lang bleef de toestand aldus, en onze politiek die van onthouding. In ieder geval wenschte de Regeering geen streven 
naar annexatie, tenzij de omstandigheden daartoe van zelf mochten leiden.

Tegen vreedzame uitbreiding van onzen invloed bestond echter geen bedenking; en het was de toenmalige Controleur C. J. Westenberg, die in het begin van het laatste deceunium der vorige eeuw meer en meer aanrakingen met de onaf hankelijke Karohoofden wist te verkrijgen. In het bijzonder won hij het vertrouwen van de beide hoofden van Kaban Djahé, den bekenden, invloedrijken $\mathrm{Pa}$ Palita en diens boudgenoot en lateren vijand $\mathrm{Pa}$ Melgah.

Meerdere tochten naar het onafhankelijk gebied werden in den loop der jaren door dien ambtenaar gemaakt, waarvan wel de belangrijkste die in Juli en Augustus 1902 ondernomen naar het Noord-Westen der Hoogvlakten om een einde te maken aan de toen zeer gespannen verhouding tusschen Langkat en de daaraan grenzende Karolandschappen.

In het jaar 1902 hadden de beide evengenoemde hoofden er zelfs in toegestemd dat een zendeling zich te Kaban Djahé kwam vestigen. Bij Gouvernements besluit van 15 Maart 1902 No 19 verleende de Regeering aan dien zendeling (den heer H. Guillaume) vergunning tot het uitoefenen van zijn dienstwerk aldaar.

Die inschikkelijkheid van de Kaban Djahésche hoofden verdroot echter tal van andere Karohoofden, in het bijzonder die vau de Westelijke oeroengs, die in den zendeling een voorlooper meenden te moeten zien vau de Europeesche planters.

Ook overigens vonden zij $\mathrm{Pa}$ Palita ons Gouveruement te vriendschappelijk gezind; met dat gevolg dat zij zich verbonden, Kaban Djahé innamen, $\mathrm{Pa}$ Palita en zijn anhhang verjoegen en de in aanbouw zijnde woning van den zendeling vernieldeu.

Zij werden door ons met de aangerichte schade belast, en toen de boeten niet spoedig genoeg betaald werden, werden als dwangmaatregel de toegangswegen naar de Hoogvlakte afgezet en bepaald dat, zoolang aan onzen eisch tot schadevergoeding geen gevolg was gegeven, de invoer van zout en de uitvoer van paarden zouden verboden blijven.

Tevens werden die matregelen door ons in het belang geoordeeld van den ons goedgezinden $\mathrm{Pa}$ Palita, die niet naliet te doen uitkomen, dat men een en ander te wijten had aan den aanval op hem en de zijnen.

Al spoedig hadden de dwangmaatregelen het gewenschte effect; eerst kozen enkele daarna meerdere hoofden de zijde van onzen 
bondgenoot, $\mathrm{Pa}$ Palita, wien het in medio 1903 weer gelukte zich te Kaban Djahé te vestigen, en toen op zijn beurt de ons nog vijandige hoofden aangreep.

Thaus was het huu beurt om de hulp van den Controleur Westenberg in te roepen tot het bewerken van den vrede.

Dit gelukte; de boeten werden betaald en van alle hoofden van XII Kota de verzekering verkregen, dat de zendeling zich ongestoord in hun midden zoude kunnen ophouden.

Door een en ander was in eeu goed deel der Hoogvlakte onze invloed zeer toegenomen met dat gevolg dat in het begin van 1904 de hoofden van een tweetal laudschappen t. w. Si Pitoe Koeta en Si Lima Koeta reeds hunne onderwerping aan het Gouvernement kwamen aaubieden. Het was echter de tocht van den toeumaligen Luiteuant-Kolonel van Daalen naar de Gajoe- en Alaslanden, die de indirecte oorzaak zoude worden tot bespoediging der annexatia.

$\mathrm{Na}$ afloop van deu tocht vau dien Hoofdofficier keerde n.l. een deel zijner troepen onder den Kapitein de Graaf over de Karohoogvlakte naar Medan terug. Door een misverstand raakte die colonne betrokken in een strijd tusschen twee partijen, gevoerd in het dorp Sebraja (landschap Soekapiring); al of niet opzettelijk in de richtiug onzer troepen afgevuurde schoten gaven aanleiding tot repressaille onzerzijds tegen een der partijen en tot inname der die partij steunende kampong Soeka Djoeloe.

De wederpartij op die wijze door ons aan de overwinning geholpeu, stond onder leiding van de meergeuoemde Pa Palita en $\mathrm{Pa}$ Melgah, die verder onze militairen gelcidden en in alles behulpzaam waren.

Dit wekte nu bij de overige Karohoofden de meening, dat $z \ddot{i j}$ eigenlijk onze militairen in het land hadden gehaald en gebruikt voor het ten onderbrengen hunner persoonlijke vijanden.

Vandaar een algemeene ontevredeuheid jegens hen, nog versterkt door de omstaudigheid, dat nog immer velen hoofden de vestiging van een zeudeling te Kabau Djahé eeu doorn in het oog bleef.

De onzen invloed het meest vijandige hoofden van de Westelijke Karolandschappen poogden van die stemming gebruik te maken en achtten de kausen thans gelukkig om te trachten nog eenmaal een verbond te vormen tegen de ons bevriende hoofden van Kaban Djahé en Lingga en dus indirect tegen het Gouvernement.

Het gelukte hun de meeste hoofdeu daartoe over te halen; men verbond zich om gezamenlijk uitbreiding van onzen invloed tegen 
te gaan; de vestiging van zendelingen op de Hoogvlakte te verhinderen en van de overige Karohoofden in dien geest medewerking te eischen, zoo noodig af te dwingen.

Aan de hoofden vau Kabau Djahé, Pa Palita en Pa Melgah, werd een uitimatum gesteld; deze weigerden hieraan te voldoen; waarop de strijd ontbrandde. Door verraad hunuer bondgenooten zouden zij op den duur het onderspit hebben moeten delven, waarom zij dringend onze hulp inriepen, welke wij hun uiteraard verplicht waren te verleenen.

Op een schriftelijke sommatie onzerzijds om de vijaudelijkheden tegen Kaban Djahé onmiddellijk te staken werd geen acht geslagen en dus vertrok op 7 September 1904 een 200 man sterke troepenmacht onder den Luitenant-Kolonel G. M. Bleckman, en begeleid door den Assistent-Resident Westenberg, naar de Hoogvlakte.

Zonder noemenswaardigen tegenstand werden de kampongs Lingga en Lingga Djoeloe genomen, waarbij de vijand pl. m. 20 dooden in onze handen achterliet; een gelijk aantal dooden, o. m. ook eenige Gajoe's, bekwam de vijand bij de inname op 15 September van de kampongs Batoe Karang en Negerie, en daarmede was alle tegenstand gebroken.

Aan de hoofden en de bevolking der tegen Kaban Djahé opgetreden landschappen werd een boete opgelegd van $\$ 15.000$, welke dra werd betaald, terwijl bovendien een gront aantal geweren werd ingeleverd.

En hiermede waren feitelijk de Karolandschappen onder ons gezag gebracht.

De in de maand September 1907 door de hoofden der zes Karolandschappen afgelegde korte verklaringen werden o. a. goedgekeurd en bekrachtigd bij besluit van 20 December d. a. v. No 14 .

Medan, 18 Mart 1909. 